\title{
Changes in nutritional parameters in diploid and triploid African catfish Clarias gariepinus following chlorpyrifos exposure
}

\author{
Samaneh Karbalaei ${ }^{1}$, Ali Karami ${ }^{1, *}$, Mahdi Ebrahimi ${ }^{2}$, \\ Mohammad Faseleh Jahromi ${ }^{3}$, Amin Ismail ${ }^{4}$, Juan Boo Liang ${ }^{3}$, Stuart L. Simpson ${ }^{5}$, \\ Sharifah Norkhadijah S. Ismail ${ }^{1}$, Yong-Meng Goh $^{2}$
}

\footnotetext{
${ }^{1}$ Laboratory of Aquatic Toxicology, Faculty of Medicine and Health Sciences, Universiti Putra Malaysia, 43400 Selangor, Malaysia

${ }^{2}$ Department of Veterinary Preclinical Sciences, Faculty of Veterinary Medicine, Universiti Putra Malaysia, 43400 Selangor, Malaysia

${ }^{3}$ Laboratory of Animal Production, Institute of Tropical Agriculture, Universiti Putra Malaysia, 43400 Selangor, Malaysia

${ }^{4}$ Department of Nutrition and Dietetics, Faculty of Medicine and Health Sciences, Universiti Putra Malaysia, 43400, Selangor, Malaysia

${ }^{5}$ Centre for Environmental Contaminants Research, CSIRO Land and Water, Locked Bag 2007, Kirrawee, NSW 2234, Australia
}

\begin{abstract}
There is a paucity of information about the influence of ploidy status on physiological parameters in organisms following contaminant stress. Also, little is known about the changes in nutritional values of fishes in response to the exposure to contaminants. Full-sibling juvenile Clarias gariepinus were exposed to 3 levels (mean measured 8.9, 17.5, or $28.0 \mu \mathrm{g} \mathrm{l}^{-1}$ ) of chlorpyrifos for $21 \mathrm{~d}$. The levels of 3 fatty acids (FAs) in the muscle were significantly different between unexposed diploid and triploid fish. In the chlorpyrifos-exposed fish, the levels of most amino acids (AAs), some FAs, protein, and moisture content were affected in the muscle of diploids, while the levels of some FAs and ash content were changed in the muscle of triploid fish. This work represents the first study of changes in FAs and proximate composition in triploid animals in response to environmental stressors. Fewer changes of nutritional values in triploid C. gariepinus under chlorpyrifos exposure may indicate higher adaptability of triploids than diploids towards environmental stressors. Significant changes in the muscle protein content and AA and FA compositions in diploid Clarias gariepinus in response to chlorpyrifos exposure suggest their application as sensitive indicators of aquatic environmental pollution.
\end{abstract}

KEY WORDS: Triploid $\cdot$ Diploid $\cdot$ Organophosphate pesticide $\cdot$ Nutritional values

\section{INTRODUCTION}

Fish are ubiquitous in most aquatic environments, representing an important component of the food chain, and are a rich source of amino acids (AAs), fatty acids (FAs), and protein to humans (Tidwell \& Allan 2001). AAs are the building blocks of proteins, which play a vital role in regulating key metabolic pathways necessary for health, growth, development, reproduction, and homeostasis of organisms (Wu 2009). FAs are a major source of energy and are

*Corresponding author: alikaramiv@gmail.com the chief constituents of cell membranes. Polyunsaturated fatty acids (PUFAs) serve as the precursors to potent lipid mediator signalling molecules, namely eicosanoids, that play various roles in therapeutic benefits for human health such as blood pressure regulation and immune responses (Dunbar et al. 2014). Lipids and proteins are the main organic components in fishes, playing major roles in the fish's life history and physiology (Tocher 2003).

Extensive application of pesticides in modern agriculture has resulted in their widespread distribution

() The authors 2017. Open Access under Creative Commons by Attribution Licence. Use, distribution and reproduction are unrestricted. Authors and original publication must be credited. 
in the environment (Yadav et al. 2015). The release of pesticides into aquatic ecosystems via spray drift, volatilization, wind erosion of soil, and accidental spillage may exert severe adverse effects on non-target organisms (Gill \& Garg 2014). Chlorpyrifos (O,Odiethyl O-3, 5, 6-trichloropyridin-2-pyridinyl phosphorothioate) is a broad-spectrum organophosphate (OP) insecticide that has been proved to be toxic to nontarget animals including fishes (Barron et al. 1991). The factors that affect the environmental concentrations of chlorpyrifos in water bodies vary according to physical parameters, namely size of the water body, properties and quality of the soil, and application concentrations. Temporal factors including rainfall events, frequency of application, and season may also contribute to the environmental concentration of chlorpyrifos. Concentrations of chlorpyrifos in small water bodies adjacent to croplands have been reported to range from 73 to over $700 \mu \mathrm{g} \mathrm{l}^{-1}$ (Moore et al. 2002, USEPA 2002, Mazanti et al. 2003).

Biochemical parameters such as protein and lipid concentrations in tissue are regarded as sensitive indicators in fish exposed to OP pesticides (Almeida et al. 2010). However, limited information is available regarding the effects of environmental contaminants on levels of nutritional parameters such as AAs and FAs (Zuraini et al. 2006). For example, changes in FA compositions were employed to evaluate stress responses to trace elements and polycyclic aromatic hydrocarbons in Mediterranean mussels Mytilus galloprovincialis (Signa et al. 2015). In another study, a 28 d exposure to sublethal chlorpyrifos concentrations decreased total protein, free AA, and ammonia contents in the gill, kidney, liver, and muscle of walking catfish Clarias batrachus (Narra et al. 2011).

Cells of triploid organisms have 3 sets of chromosomes, compared to 2 in diploids (Piferrer et al. 2009). The unbalanced chromosomal number in triploid fish cells may hinder meiotic division and the production of gametes (Gold \& Avise 1976). The channelled energy from reproduction into somatic growth may cause the better growth performance of triploid fish as compared to their diploid counterparts (e.g. Fast et al. 1995, Karami et al. 2016a). Triploidy has been shown to be naturally occurring in several fish species (e.g. Carassius auratus; Murayama et al. 1986, Xiao et al. 2011). Despite the presence of triploid fish in aquatic environments and their promising application in the aquaculture industry (e.g. salmonids, Mayer 2015), reports on the impacts of contaminants on the physiological responses of polyploid fish are limited to our recent studies (e.g. Karami et al. 2015b, $2016 a, b, c, d)$.
African catfish C. gariepinus is a major source of animal protein for humans and animals in tropical and subtropical regions (Adewolu et al. 2008) and is farmed in and around agricultural lands (Marimuthu et al. 2013). This species is especially suited for aquaculture due to its high fecundity and its resistance to poor oxygen content due to auxiliary respiratory organs (Toko et al. 2007).

The primary objectives of this study were to compare AA, FA, and proximate compositions in the skeletal white muscle of unexposed diploid and triploid C. gariepinus and to investigate the effect of chlorpyrifos exposure on these nutritional values in diploid and triploid C. gariepinus. The chlorpyrifos concentrations used in the study (nominal concentrations) were 50,100 , and $150 \mu \mathrm{g} \mathrm{l}^{-1}$, levels that are within the range observed in small water bodies or what has been used in recent ecotoxicological studies (Nwani et al. 2013, Jin et al. 2015).

\section{MATERIALS AND METHODS}

\section{Triploidy induction}

Broodstock were obtained from local farmers in Selangor, Malaysia, and raised for 12 mo in 20001 fiberglass tanks. Triploid Clarias gariepinus were produced as described by Karami et al. (2010). Briefly, mature male and female C. gariepinus were injected with Ovaprim ${ }^{\circledR} 10 \mathrm{~h}$ before breeding. Eggs and milt were gently mixed with a bird feather for $3 \mathrm{~min}$ and then divided into 2 batches. Triploids were produced from the first group by cold-shocking of the fertilized eggs at $5^{\circ} \mathrm{C}$ for $40 \mathrm{~min}$. The second batch received no treatment and, therefore, was considered as diploid. Each batch of eggs was transferred to a 20001 fiberglass tank filled with 5001 UV-sterilized water. To confirm successful initial triploidy induction, the chromosomal spreads of 20 larvae from the cold shock treated groups were prepared according to the method of Karami et al. (2015a). Larvae were initially fed ad libitum with freshly hatched Artemia nauplii 3 times a day for $1 \mathrm{wk}$. Then, fish were fed at a rate of 5 to $10 \%$ of body weight with fish powder (Cargill, crude protein: 38 to $40 \%$, crude fat: $3 \%$, crude fiber: $6 \%$, moisture content: $13 \%$ ) for 2 wk and then with commercial pellets (Star Feed, crude protein: 45\%, crude fat: $6 \%$, crude fiber: $4 \%$, moisture content: $12 \%$ ) for $11 \mathrm{wk}$ prior to the start of the experiment. Total lengths and weights of fishes were measured after 14 wk of growth. 


\section{Triploidy confirmation}

Individual fish from the shocked group were labelled with plastic T-bar anchor tags followed by blood sampling. The ploidy status of each fish from the shocked group was confirmed by determining nuclear DNA content of erythrocytes using flow cytometry (LSR Fortessa, BD Biosciences) (Karami et al. 2016a).

\section{Experimental design}

Prior to exposure, 14 wk old diploid and triploid fish were acclimatized in $84 \mathrm{l}$ glass aquaria filled with UV-treated water (1 fish per aquarium, 5 fish per replicate per treatment) for $1 \mathrm{wk}$. Stock solutions of chlorpyrifos (analytical standard grade, SigmaAldrich) were prepared in HPLC-grade acetone (Fisher Scientific) every $3 \mathrm{~d}$ and kept refrigerated in dark bottles. Following OECD guidelines (OECD 1994,2011 ), a solvent (acetone $<0.001 \% \mathrm{~V} / \mathrm{V}$ ) control group was applied in our experiment to assess the toxicity of acetone. Diploids (mean \pm SD weight: $140 \pm 19 \mathrm{~g}$, total length: $27.9 \pm 1.4 \mathrm{~cm} ; \mathrm{n}=25$ ) and triploids (weight: $184 \pm 31 \mathrm{~g}$, total length: $29.7 \pm$ $3.2 \mathrm{~cm} ; \mathrm{n}=25)$ were exposed to 1 of 3 nominal concentrations of chlorpyrifos $\left(50,100\right.$, or $\left.150 \mu \mathrm{g} \mathrm{l}^{-1}\right)$ for $21 \mathrm{~d}$. Besides a solvent control group, a negative control (chlorpyrifos-free water) group was used for diploid and triploid fishes. To minimize the stress on the fish posed by the water change, every day, $70 \%$ of the test solution was refreshed in the morning and $30 \%$ in the evening ( $10 \mathrm{~h}$ later) (Karami et al. 2016a). During the exposure period, fish were fed ad libitum once daily with commercial pellets (Star Feed). Adequate aeration was provided using airstone blowers. Water quality parameters were measured every $3 \mathrm{~d}$ throughout the experiment, mean \pm $\mathrm{SD}(\mathrm{n}=42)$ : temperature $28.0 \pm 0.97^{\circ} \mathrm{C}, \mathrm{pH} 6.81 \pm$ 0.34 , dissolved oxygen $6.59 \pm 0.78 \mathrm{mg} \mathrm{l}^{-1}$, total hardness $58.1 \pm 4.4 \mathrm{mg} \mathrm{CaCO}_{3}$, alkalinity $37 \pm 6.5 \mathrm{mg}$ $\mathrm{CaCO}_{3}$, and salinity $<1 \mathrm{mg} \mathrm{l}^{-1}$. At the end of the experiment, fish were sacrificed by an overdose of clove oil. The skeletal muscles (tissue samples) were taken from the same section of each organism for analysis of each parameter to minimize experimental variability.

\section{Measured chlorpyrifos concentrations}

Every $3 \mathrm{~d}$, water samples were collected in $500 \mathrm{ml}$ amber glass bottles (Schott) from each treatment
30 min before and after water changes in the morning and also $30 \mathrm{~min}$ before water change in the evening. Water samples were analysed for chlorpyrifos according to the procedure of Mamun et al. (2009) with some modifications as described by Karami et al. (2016a). Chlorpyrifos concentrations were analysed by gas chromatography (GC, Agilent 6890N) equipped with an electron capture detector and an HP-5 capillary column $(30 \mathrm{~m} \times 0.25 \mathrm{~mm}$ inside diameter $\times 0.25 \mu \mathrm{m}$ film thickness). The carrier gas was nitrogen at a flow rate of $1 \mathrm{ml} \mathrm{min}{ }^{-1}$. The extraction recovery was calculated by spiking the distilled water with chlorpyrifos at concentrations of $0.1,0.01$, and $0.001 \mu \mathrm{g} \mathrm{ml}^{-1}$. Average recoveries (SD) $(\mathrm{n}=3)$ for $0.1,0.01$, and $0.001 \mathrm{\mu g} \mathrm{ml}^{-1}$ spiked samples were 110 (3.1), 99.2 (4.8), and $88.3 \%$ (2.6), respectively.

\section{AA analysis}

The AA levels of muscle samples were determined with an AccQ-Fluor ${ }^{\mathrm{TM}}$ Reagent Kit (Waters) using the AccQ-Tag ${ }^{\mathrm{TM}}$ AA analysis method. Muscle tissues $(0.2 \mathrm{~g})$ were added to $5 \mathrm{ml}$ of $6 \mathrm{M} \mathrm{HCl}$ ( $\mathrm{R} \& \mathrm{M}$ Chemicals) in a high temperature resistant bottle and incubated in an oven at $105^{\circ} \mathrm{C}$ for $24 \mathrm{~h}$ (AOAC 1984). The solution was diluted to $100 \mathrm{ml}$ with distilled water and filtered through a syringe filter (PVDF, $0.2 \mu \mathrm{m}$, Jet Biofil). Then, $40 \mu \mathrm{l}$ of the internal standard Laminobutyric acid (AABA, Sigma) was added to $960 \mu \mathrm{l}$ of treated sample. For derivatization, $10 \mu \mathrm{l}$ of sample was mixed with $70 \mu \mathrm{l}$ of AccQ-Fluor borate buffer reagent and $20 \mu \mathrm{l}$ of AccQ-Fluor reagent. Prior to injection into HPLC, the derivatized compound was heated on a digital block heater at $55^{\circ} \mathrm{C}$ for 10 min. AA composition was analysed using HPLC (Waters Alliance System e2695) equipped with fluorescence detection (Waters 2475 multi- $\lambda$ fluorescence detector) set at $250 \mathrm{~nm}$ excitation and $395 \mathrm{~nm}$ emission. AAs were separated on an AccQ-Tag AA analysis column $(150 \times 3.9 \mathrm{~mm}, 4 \mu \mathrm{m}, \mathrm{RP} 18$, Waters $)$. The column was operated at $31^{\circ} \mathrm{C}$. The eluent system consisted of the aqueous solution of AccQ-Tag ${ }^{\mathrm{TM}}$ eluent reagent (Waters) and $60 \%$ acetonitrile (Fisher

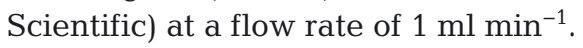

\section{FA analysis}

Total FA of muscle tissue was extracted according to the method of Rajion et al. (1985) as described by Ebrahimi et al. (2012). Briefly, $7 \mathrm{ml}$ of chloroformmethanol (2:1 V/V, R \& M Chemicals) was mixed 
with $1 \mathrm{~g}$ of minced muscle and shaken by vortex. The mixture was centrifuged at $3000 \mathrm{rpm}$ for $5 \mathrm{~min}$, and the lower layer was dried by nitrogen gas after transferring to the methylation tube. The extracted FAs were transmethylated to their FA methyl esters (FAME) using $0.66 \mathrm{M} \mathrm{KOH}$ and $14 \%$ methanolic boron trifluoride (Sigma) (AOAC 1999). The FAME was separated and quantified by gas liquid chromatography using an Agilent 7890A GC system equipped with a $100 \mathrm{~m} \times 0.25 \mathrm{~mm}$ inside diameter (0.20 $\mu \mathrm{m}$ film thickness) Supelco SP-2560 capillary column and a flame ionization detector. Helium was used as the carrier gas. The column temperature program was set at $100^{\circ} \mathrm{C}$, held for $2 \mathrm{~min}$, heated to $170^{\circ} \mathrm{C}$ at $10^{\circ} \mathrm{C} \mathrm{min}{ }^{-1}$, held for $2 \mathrm{~min}$, heated again to $220^{\circ} \mathrm{C}$ at $7.5^{\circ} \mathrm{C} \mathrm{min}^{-1}$, and subsequently held for $20 \mathrm{~min}$. The injector and detector temperatures were kept at 250 and $300^{\circ} \mathrm{C}$, respectively. A reference standard (mix C4-C24 methyl esters, Sigma-Aldrich), conjugated linoleic acid standard mixture (O-5507, Sigma-Aldrich) and conjugated linolenic acid standard mixture (47792, Supelco) were used to measure recoveries and correction factors for the evaluation of individual FA levels.

\section{Proximate composition analysis}

Proximate composition (protein, lipid, moisture, and ash) of muscle tissue was determined according to the procedures of AOAC (2000). Protein content was assessed by the Kjeldahl method (protein = total nitrogen $\times 6.25$ ). Lipid was extracted with petroleum ether (boiling point, 60 to $80^{\circ} \mathrm{C}, \mathrm{R} \& \mathrm{M}$ Chemicals) using a Soxhlet extractor. Moisture content was quantified by drying the sample in an oven at $105^{\circ} \mathrm{C}$ for $24 \mathrm{~h}$ until obtaining a constant weight. Ash content was assessed by incinerating a muscle sample at $550^{\circ} \mathrm{C}$ in a Thermolyne 62700 muffle furnace.

\section{Statistical analysis}

Data were assessed for normality with the ShapiroWilks test and for homogeneity of variance with Levene's test. Data were log transformed where necessary. The AA, FA, and proximate compositions of the fish belonging to the solvent and negative control groups were compared using Student's $t$-test (OECD 2011). Data from the 2 groups were pooled if no significant differences were observed (OECD 2011). AA and FA levels and protein, ash, lipid, and moisture contents of diploid and triploid fish from the control groups were compared using Student's t-test. Within each ploidy, alterations in the AA and FA levels and protein, lipid, moisture, and ash contents across chlorpyrifos concentrations were analysed using 1way ANOVA, with post hoc comparisons using Tukey's test if a significant difference $(p<0.05)$ was found. All statistical analyses were performed using IBM SPSS Statistics (v.22).

\section{RESULTS}

\section{Measured chlorpyrifos concentrations}

The measured chlorpyrifos concentrations in 50, 100 , and $150 \mathrm{\mu g} \mathrm{l}^{-1}$ treatments were (mean $\pm \mathrm{SD}$ ) $8.9 \pm 2.7,17.5 \pm 5.8$, and $28.0 \pm 6.3 \mu \mathrm{g} \mathrm{l}^{-1}$, respectively. In the negative and solvent control groups, the chlorpyrifos concentration was below the detection limit. The detection limit was $0.002 \mu \mathrm{g} \mathrm{l}^{-1}$ for the tested chlorpyrifos.

\section{Effect of chlorpyrifos on proximate composition}

Moisture, lipid, protein, and ash contents in Clarias gariepinus muscle were not significantly different between solvent and negative control groups in diploid or triploid fish (Student's $t$-test, $\mathrm{p}>0.05$ ). The muscle tissues of diploids in the $28 \mu \mathrm{g} \mathrm{l}^{-1}$ chlorpyrifos treatments had significantly $(\mathrm{p}<0.05)$ lower protein (ANOVA， $F_{3,21}=15.2$; Fig. $\left.1 \mathrm{~A}\right)$ content $(1.10 \%)$. Moisture content (ANOVA, $F_{3,21}=3.98$; Fig.1B) was greater $(1.02 \%)$ in the $28 \mathrm{\mu g} \mathrm{l}^{-1}$ chlorpyrifos treatment compared to the $8.9 \mathrm{\mu g} \mathrm{l}^{-1}$ chlorpyrifos treatment in diploid fish. Also, ash content (ANOVA, $F_{3,21}=4.57$; Fig. 1C) was greater $(2.24 \%)$ in the $17.5 \mathrm{\mu g} \mathrm{l}^{-1}$ chlorpyrifos treatment compared to the $8.9 \mathrm{\mu g} \mathrm{l}^{-1}$ chlorpyrifos treatment in triploid fish.

\section{Effect of chlorpyrifos on AA levels}

Individual AA levels or their sum (total AAs) were not significantly different between solvent and negative control groups in diploid and triploid fish (Student's $t$-test, $\mathrm{p}>0.05)$, so they were pooled together as total AAs for subsequent analyses. There were no significant differences in AA levels between unexposed diploid and triploid C. gariepinus (Student's $t$ test, $\mathrm{p}>0.05$ ).

The muscles of diploids in the $28 \mu \mathrm{g} \mathrm{l^{-1 }}$ chlorpyrifos treatments had significantly $(\mathrm{p}<0.05)$ decreased lev- 

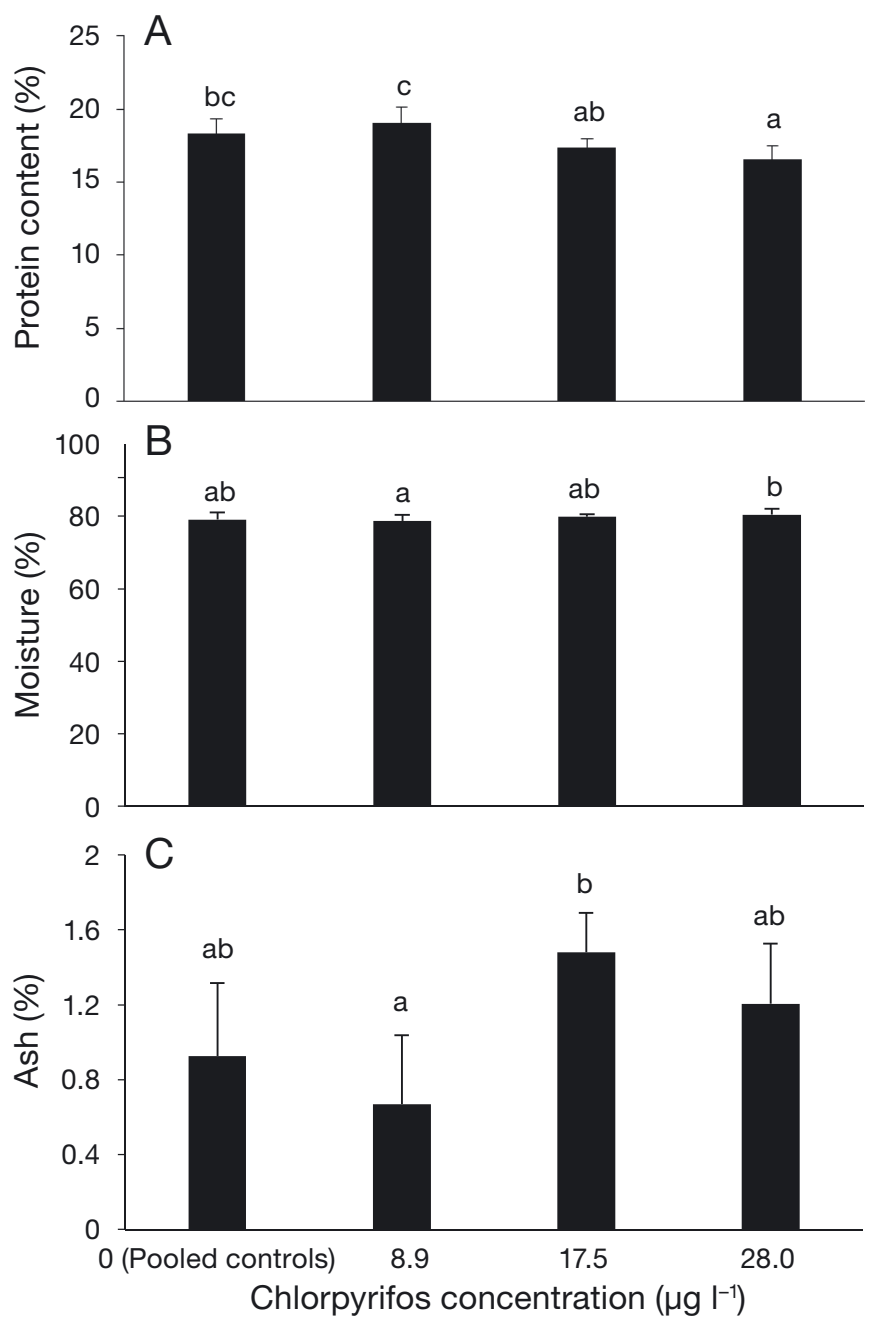

Fig. 1. Mean + SD of $(\mathrm{A})$ protein and $(\mathrm{B})$ moisture contents in the muscle of diploid and (C) ash content in the muscle of triploid Clarias gariepinus across different chlorpyrifos treatments. Bars with different letters are significantly different ( $\mathrm{p}<0.05$, Tukey's multiple range tests); $\mathrm{n}=5$ for all treatments except for pooled controls $\left(0 \mu \mathrm{g} \mathrm{l}^{-1}\right)$, where $\mathrm{n}=10$

els of aspartic acid (1.09 times) (ANOVA, $\left.F_{4,20}=9.10\right)$, serine (1.11 times) (ANOVA, $\left.F_{4,20}=8.08\right)$, glutamic acid (1.10 times) (ANOVA, $F_{4,20}=10.18$ ), histidine (1.18 times) (ANOVA, $\left.F_{4,20}=5.34\right)$, alanine (1.08 times) (ANOVA, $\left.F_{4,20}=4.81\right)$, tyrosine (1.12 times) (ANOVA, $\left.F_{4,20}=9.59\right)$, valine (1.12 times) (ANOVA, $\left.F_{4,20}=6.27\right)$, lysine (1.11 times) (ANOVA, $F_{4,20}=$ $8.21)$, isoleucine (1.12 times) (ANOVA, $F_{4,20}=6.31$ ), leucine (1.10 times) (ANOVA, $F_{4,20}=8.00$ ), phenylalanine (1.12 times) (ANOVA, $\left.F_{4,20}=6.98\right)$, and total AAs (1.10 times) (ANOVA, $F_{4,20}=8.47$ ) compared to the control group. In triploids, only the levels of cysteine were significantly lower (1.37 times) in the $17.5 \mathrm{\mu g} \mathrm{l}^{-1}$ treatment compared to the $8.9 \mathrm{\mu g} \mathrm{l}^{-1}$ treat- ment (ANOVA, $F_{4,20}=3.79$ ). The AAs for which significant changes in AA levels were observed across different chlorpyrifos exposures are shown in Table 1.

\section{Effect of chlorpyrifos on FA levels}

In both ploidies, the level of palmitic acid (C16:0) was significantly different between negative and solvent controls (Student's $t$-test, $\mathrm{p}<0.05$ ). In triploids, acetone treatment resulted in significant differences in the level of total PUFAs compared to the negative control group. The levels of arachidonic acid (C20: $4 \mathrm{n}-6$ ), total saturated FAs (SFAs), and total unsaturated FAs (UFAs) were significantly different between the control and solvent controls in diploid fish (Student's $t$-test, $\mathrm{p}<0.05)$. The levels of most of the FAs were not significantly different between the control diploid and triploid fish except for myristic acid (C14:0) (Student's $t$-test, $t_{18}=-2.32$ ), which was 1.11 times higher in triploids, and docosahexaenoic acid (C22:6n-3) (Student's $t$-test, $t_{18}=2.44$ ) and total omega-3 FAs (Student's $t$-test, $t_{18}=2.35$ ), which were 1.23 and 1.16 times greater in diploids than triploids, respectively.

In diploids, exposure to $17.5 \mathrm{\mu g} \mathrm{l}^{-1}$ chlorpyrifos resulted in significantly $(\mathrm{p}<0.05)$ higher levels of $\mathrm{C} 16: 0$ (1.02 times) (ANOVA, $F_{4,20}=4.19$ ) and total SFAs (1.03 times) (ANOVA, $\left.F_{4,20}=4.62\right)$ but lower total UFAs (1.01 times) (ANOVA, $F_{4,20}=4.62$ ) compared to the control group. In triploids, the levels of stearic acid (C18:0) (ANOVA, $\left.F_{4,21}=4.44\right)$ and docosapentaenoic acid (C22:5n-3) (ANOVA, $\left.F_{4,21}=3.44\right)$ were significantly greater (1.14 and 1.72 times, respectively) in the $8.9 \mathrm{\mu g} \mathrm{l}^{-1}$ chlorpyrifos treatments, and the levels of C22:6n-3 (ANOVA, $F_{4,21}=3.29$ ) and total omega-3 fatty acids (ANOVA, $F_{4,21}=3.26$ ) were significantly greater (1.41 and 1.33 times, respectively) in the $17.5 \mu \mathrm{g} \mathrm{l}^{-1}$ chlorpyrifos treatments compared to the control group. Also, the level of C16:0 (ANOVA, $\left.F_{4,20}=6.77\right)$ was significantly lower (1.11 times) in the $17.5 \mathrm{\mu g} \mathrm{l}^{-1}$ chlorpyrifos treatment compared to the control group. The level of total SFAs was significantly lower (1.08 times) (ANOVA, $\left.F_{4,21}=4.84\right)$ in the $17.5 \mu \mathrm{g} \mathrm{l}^{-1}$ chlorpyrifos treatment compared to the $8.9 \mathrm{ug} \mathrm{l}^{-1}$ chlorpyrifos treatment. In contrast, the level of total UFAs was significantly greater (1.05 times) (ANOVA, $F_{4,21}=4.84$ ) in the $17.5 \mu \mathrm{g} \mathrm{l}^{-1}$ chlorpyrifos treatment compared to the $8.9 \mathrm{\mu g} \mathrm{l}^{-1}$ chlorpyrifos treatment. The muscle FA levels in diploid and triploid fish in response to different chlorpyrifos exposures are summarized in Table 2 . 
Table 1. Amino acid composition ( $\mathrm{mg} \mathrm{g}^{-1}$ wet weight) in the skeletal muscle of diploid and triploid Clarias gariepinus. Data are mean $\pm \mathrm{SD} ; \mathrm{n}=5$ for all treatments except for $0 \mu \mathrm{g} \mathrm{l}^{-1}$ (pooled controls), where $\mathrm{n}=10$. Values in the same line with different letters indicate differences among groups $(p<0.05$, Tukey's multiple range tests). *Significant $(\mathrm{p}<0.05)$ differences compared with control value

\begin{tabular}{|c|c|c|c|c|c|}
\hline \multirow{2}{*}{$\begin{array}{l}\text { Amino } \\
\text { acid }\end{array}$} & \multirow[t]{2}{*}{ Ploidy } & \multicolumn{4}{|c|}{ - Chlorpyrifos concentration $\left(\mu \mathrm{g}^{-1}\right)$} \\
\hline & & 0 & 8.9 & 17.5 & 28.0 \\
\hline \multirow{2}{*}{$\begin{array}{l}\text { Aspartic } \\
\text { acid }\end{array}$} & Diploid* & $1.81 \pm 0.07^{b}$ & $1.82 \pm 0.03^{b}$ & $1.73 \pm 0.04^{\mathrm{ab}}$ & $1.65 \pm 0.04^{\mathrm{a}}$ \\
\hline & Triploid & $1.71 \pm 0.08$ & $1.77 \pm 0.08$ & $1.76 \pm 0.07$ & $1.80 \pm 0.09$ \\
\hline \multirow[t]{2}{*}{ Serine } & Diploid* & $0.75 \pm 0.04^{\mathrm{b}}$ & $0.74 \pm 0.005^{\mathrm{b}}$ & $0.72 \pm 0.006^{\mathrm{ab}}$ & $0.67 \pm 0.01^{\mathrm{a}}$ \\
\hline & Triploid & $0.73 \pm 0.02$ & $0.762 \pm 0.03$ & $0.72 \pm 0.01$ & $0.73 \pm 0.01$ \\
\hline \multirow{2}{*}{$\begin{array}{l}\text { Glutamic } \\
\text { acid }\end{array}$} & Diploid* & $2.71 \pm 0.1^{\mathrm{b}}$ & $2.67 \pm 0.008^{\mathrm{b}}$ & $2.59 \pm 0.03^{\mathrm{ab}}$ & $2.46 \pm 0.07^{\mathrm{a}}$ \\
\hline & Triploid & $2.63 \pm 0.15$ & $2.721 \pm 0.1$ & $2.58 \pm 0.02$ & $2.67 \pm 0.06$ \\
\hline \multirow[t]{2}{*}{ Glycine } & Diploid & $0.74 \pm 0.07$ & $0.78 \pm 0.01$ & $0.70 \pm 0.02$ & $0.67 \pm 0.02$ \\
\hline & Triploid & $0.78 \pm 0.07$ & $0.712 \pm 0.04$ & $0.84 \pm 0.02$ & $0.80 \pm 0.07$ \\
\hline \multirow[t]{2}{*}{ Histidine } & Diploid* & $0.44 \pm 0.04^{\mathrm{b}}$ & $0.45 \pm 0.01^{\mathrm{b}}$ & $0.41 \pm 0.007^{\mathrm{b}}$ & $0.37 \pm 0.01^{\mathrm{a}}$ \\
\hline & Triploid & $0.42 \pm 0.04$ & $0.44 \pm 0.06$ & $0.414 \pm 0.01$ & $0.44 \pm 0.03$ \\
\hline \multirow[t]{2}{*}{ Arginine } & Diploid & $1.09 \pm 0.09$ & $1.11 \pm 0.05$ & $1.1 \pm 0.01$ & $1.02 \pm 0.01$ \\
\hline & Triploid & $0.98 \pm 0.08$ & $1.103 \pm 0.05$ & $0.97 \pm 0.09$ & $1.11 \pm 0.07$ \\
\hline \multirow[t]{2}{*}{ Threonine } & Diploid & $0.85 \pm 0.05$ & $0.843 \pm 0.009$ & $0.82 \pm 0.01$ & $0.78 \pm 0.03$ \\
\hline & Triploid & $0.83 \pm 0.05$ & $0.79 \pm 0.03$ & $0.81 \pm 0.01$ & $0.83 \pm 0.01$ \\
\hline \multirow[t]{2}{*}{ Alanine } & Diploid* & $1.01 \pm 0.04^{b}$ & $1.00 \pm 0.01^{\mathrm{ab}}$ & $0.97 \pm 0.03^{\mathrm{ab}}$ & $0.93 \pm 0.02^{\mathrm{a}}$ \\
\hline & Triploid & $0.98 \pm 0.03$ & $1.01 \pm 0.4$ & $0.97 \pm 0.01$ & $1.01 \pm 0.03$ \\
\hline \multirow[t]{2}{*}{ Proline } & Diploid & $0.57 \pm 0.02$ & $0.59 \pm 0.01$ & $0.57 \pm 0.01$ & $0.54 \pm 0.01$ \\
\hline & Triploid & $0.58 \pm 0.01$ & $0.56 \pm 0.02$ & $0.56 \pm 0.01$ & $0.59 \pm 0.02$ \\
\hline \multirow[t]{2}{*}{ Cysteine } & Diploid & $0.11 \pm 0.01$ & $0.115 \pm 0.01$ & $0.11 \pm 0.003$ & $0.10 \pm 0.01$ \\
\hline & Triploid & $0.09 \pm 0.01^{\mathrm{ab}}$ & $0.11 \pm 0.008^{b}$ & $0.08 \pm 0.02^{\mathrm{a}}$ & $0.1 \pm 0.02^{\mathrm{ab}}$ \\
\hline \multirow[t]{2}{*}{ Tyrosine } & Diploid $^{*}$ & $0.63 \pm 0.03^{\mathrm{b}}$ & $0.62 \pm 0.01^{\mathrm{ab}}$ & $0.60 \pm 0.01^{\mathrm{ab}}$ & $0.56 \pm 0.02^{\mathrm{a}}$ \\
\hline & Triploid & $0.60 \pm 0.04$ & $0.617 \pm 0.02$ & $0.60 \pm 0.01$ & $0.61 \pm 0.01$ \\
\hline \multirow[t]{2}{*}{ Valine } & Diploid* & $0.8 \pm 0.05^{\mathrm{b}}$ & $0.79 \pm 0.008^{\mathrm{ab}}$ & $0.76 \pm 0.01^{\mathrm{ab}}$ & $0.71 \pm 0.03^{\mathrm{a}}$ \\
\hline & Triploid & $0.78 \pm 0.03$ & $0.79 \pm 0.03$ & $0.78 \pm 0.02$ & $0.78 \pm 0.01$ \\
\hline \multirow[t]{2}{*}{ Methionine } & Diploid & $0.47 \pm 0.06$ & $0.54 \pm 0.02$ & $0.46 \pm 0.005$ & $0.43 \pm 0.05$ \\
\hline & Triploid & $0.43 \pm 0.07$ & $0.47 \pm 0.03$ & $0.43 \pm 0.08$ & $0.49 \pm 0.04$ \\
\hline \multirow[t]{2}{*}{ Lysine } & Diploid* & $1.71 \pm 0.09^{b}$ & $1.68 \pm 0.01^{\mathrm{b}}$ & $1.62 \pm 0.02^{\mathrm{ab}}$ & $1.53 \pm 0.04^{\mathrm{a}}$ \\
\hline & Triploid & $1.67 \pm 0.1$ & $1.74 \pm 0.08$ & $1.64 \pm 0.03$ & $1.68 \pm 0.05$ \\
\hline \multirow[t]{2}{*}{ Isoleucine } & Diploid* & $0.72 \pm 0.04^{b}$ & $0.71 \pm 0.009^{b}$ & $0.68 \pm 0.009^{\mathrm{ab}}$ & $0.64 \pm 0.02^{\mathrm{a}}$ \\
\hline & Triploid & $0.70 \pm 0.04$ & $0.70 \pm 0.03$ & $0.70 \pm 0.01$ & $0.71 \pm 0.01$ \\
\hline \multirow[t]{2}{*}{ Leucine } & Diploid* & $1.42 \pm 0.06^{\mathrm{b}}$ & $1.41 \pm 0.02^{\mathrm{b}}$ & $1.37 \pm 0.01^{\mathrm{ab}}$ & $1.29 \pm 0.05^{\mathrm{a}}$ \\
\hline & Triploid & $1.38 \pm 0.08$ & $1.366 \pm 0.06$ & $1.36 \pm 0.02$ & $1.41 \pm 0.03$ \\
\hline \multirow{2}{*}{$\begin{array}{l}\text { Phenyl- } \\
\text { alanine }\end{array}$} & Diploid* & $0.74 \pm 0.03^{b}$ & $0.73 \pm 0.01^{\mathrm{b}}$ & $0.71 \pm 0.01^{\mathrm{ab}}$ & $0.66 \pm 0.02^{\mathrm{a}}$ \\
\hline & Triploid & $0.72 \pm 0.03$ & $0.72 \pm 0.03$ & $0.718 \pm 0.02$ & $0.74 \pm 0.02$ \\
\hline \multirow{2}{*}{$\begin{array}{l}\text { Total amino } \\
\text { acids }\end{array}$} & Diploid ${ }^{*}$ & $15.6 \pm 0.73^{b}$ & $15.5 \pm 0.13^{b}$ & $14.9 \pm 0.18^{\mathrm{ab}}$ & $14.1 \pm 0.48^{\mathrm{a}}$ \\
\hline & Triploid & $16.09 \pm 1.02$ & $16.72 \pm 0.75$ & $15.86 \pm 0.25$ & $16.57 \pm 0.40$ \\
\hline
\end{tabular}

\section{Effect of ploidy on growth}

Triploid fish were $31 \%$ heavier and $6 \%$ longer than diploid fish at the end of the $14 \mathrm{wk}$ rearing period (Fig. 2).

\section{DISCUSSION}

The unbalanced chromosome number in triploid fish led to considerable differences in AA composition, omega-3 FAs, and protein of diploid and triploid Clarias gariepinus white muscle tissue after exposure to an OP pesticide. Changes in protein, AA, and FA compositions in animals can be protective strategies under environmental stressors (Silva et al. 2017).

Lack of significant differences in the proximate composition of white muscle between diploid and triploid control groups was consistent with the comparable whole-body proximate composition observed for diploid and triploid Oncorhynchus mykiss (Oliva-Teles \& Kaushik 1990). In line with the results of the present study, diploid and triploid $C$. gariepinus had a similar proximate composition in skin gelatin (Karami et al. 2016b). Despite the same protein content per gram of muscle in diploid and triploid C. gariepinus, triploid fish were heavier in weight and of a longer body length than diploid fish, and this should guarantee a higher total protein yield in the aquaculture industry.

AAs play a significant role in metabolism and immunity against diseases in organisms (Wu 2013). Similar AA composition in the diploid and triploid control groups is in agreement with our recent study that demonstrated AA composition did not change in the 
Table 2. Fatty acid composition (\% total fatty acids) in the muscle of diploid and triploid Clarias gariepinus across different chlorpyrifos concentrations. Data are mean $\pm \mathrm{SD}_{i} \mathrm{n}=5$. Values in the same line with different letters indicate differences among groups ( $\mathrm{p}<0.05$, Tukey's multiple range tests). (D) indicates dropped (negative control group dropped according to OECD [2011] guidelines); (P) indicates pooled (negative and solvent controls pooled according to OECD [2011] guidelines). ${ }^{*}$ Significant $(\mathrm{p}<0.05)$ differences compared with control value. SFAs: saturated fatty acids; MUFAs: monounsaturated fatty acids; PUFAs: polyunsaturated fatty acids; UFAs: unsaturated fatty acids

\begin{tabular}{|c|c|c|c|c|c|c|}
\hline \multirow{3}{*}{ Fatty acid } & \multirow[t]{3}{*}{ Ploidy } & \multicolumn{5}{|c|}{ Chlorpyrifos concentration $\left(\mu g \mathrm{l}^{-1}\right)$} \\
\hline & & \multicolumn{2}{|c|}{0 (control group) } & \multirow[t]{2}{*}{8.9} & \multirow[t]{2}{*}{17.5} & \multirow[t]{2}{*}{28.0} \\
\hline & & Negative & Solvent & & & \\
\hline \multirow[t]{2}{*}{ C14:0 } & Diploid & $1.76 \pm 0.2$ & $1.61 \pm 0.1$ & $2.30 \pm 0.2$ & $1.93 \pm 0.2$ & $1.88 \pm 0.2$ \\
\hline & Triploid & $2.04 \pm 0.2$ & $1.73 \pm 0.3$ & $2.55 \pm 0.5$ & $1.74 \pm 0.3$ & $2.55 \pm 0.6$ \\
\hline \multirow[t]{2}{*}{ C16:0 } & Diploid* & $27.2 \pm 0.8(\mathrm{D})$ & $28.6 \pm 0.2^{\mathrm{a}}$ & $27.7 \pm 0.6^{\mathrm{ab}}$ & $29.4 \pm 1.4^{\mathrm{b}}$ & $28.5 \pm 0.5^{\mathrm{ab}}$ \\
\hline & Triploid* & $27.8 \pm 0.5(\mathrm{D})$ & $29.6 \pm 1.4^{\mathrm{b}}$ & $28.6 \pm 1.02^{b}$ & $26.6 \pm 0.5^{\mathrm{a}}$ & $29.1 \pm 1.2^{\mathrm{b}}$ \\
\hline \multirow[t]{2}{*}{ C18:0 } & Diploid & $10.0 \pm 0.4$ & $9.86 \pm 0.3$ & $10.0 \pm 0.6$ & $10.2 \pm 1.0$ & $9.95 \pm 0.9$ \\
\hline & Triploid* & $9.74 \pm 0.5^{\mathrm{a}}(\mathrm{P})$ & $9.07 \pm 0.4^{\mathrm{a}}(\mathrm{P})$ & $10.8 \pm 0.9^{\mathrm{b}}$ & $10.3 \pm 0.8^{\mathrm{ab}}$ & $9.89 \pm 0.5^{\mathrm{ab}}$ \\
\hline \multirow[t]{2}{*}{ Total SFAs } & Diploid* & $39.0 \pm 0.9(\mathrm{D})$ & $40.0 \pm 0.4^{\mathrm{a}}$ & $40.0 \pm 0.2^{\mathrm{ab}}$ & $41.5 \pm 1.3^{\mathrm{b}}$ & $40.4 \pm 0.7^{\mathrm{ab}}$ \\
\hline & Triploid & $39.6 \pm 0.4^{\mathrm{ab}}(\mathrm{P})$ & $40.4 \pm 0.6^{\mathrm{ab}}(\mathrm{P})$ & $41.9 \pm 2.4^{\mathrm{b}}$ & $38.7 \pm 0.9^{\mathrm{a}}$ & $41.5 \pm 2.1^{\mathrm{b}}$ \\
\hline \multirow[t]{2}{*}{ C16:1 } & Diploid & $3.80 \pm 0.3$ & $3.94 \pm 0.2$ & $4.20 \pm 0.5$ & $3.94 \pm 0.6$ & $3.76 \pm 0.6$ \\
\hline & Triploid & $4.07 \pm 0.4$ & $4.37 \pm 0.7$ & $3.94 \pm 0.7$ & $3.32 \pm 0.6$ & $4.1 \pm 0.5$ \\
\hline \multirow[t]{2}{*}{ C18:1n-9 } & Diploid & $24.2 \pm 1.3$ & $25.1 \pm 1.5$ & $23.4 \pm 3.2$ & $25.3 \pm 2.8$ & $23.6 \pm 3.9$ \\
\hline & Triploid & $25.6 \pm 1.7$ & $26.7 \pm 1.8$ & $25.2 \pm 2.1$ & $23.6 \pm 4.1$ & $25.1 \pm 2.6$ \\
\hline \multirow[t]{2}{*}{ Total MUFAs } & Diploid & $28.0 \pm 1.6$ & $29.1 \pm 1.7$ & $27.6 \pm 3.8$ & $29.3 \pm 3.4$ & $27.4 \pm 4.5$ \\
\hline & Triploid & $29.1 \pm 2.1$ & $31.1 \pm 2.4$ & $29.2 \pm 2.7$ & $26.95 \pm 4.7$ & $29.2 \pm 3.2$ \\
\hline \multirow[t]{2}{*}{ C18:3n-3 } & Diploid & $0.95 \pm 0.1$ & $1.02 \pm 0.1$ & $1.12 \pm 0.1$ & $1.07 \pm 0.3$ & $0.83 \pm 0.08$ \\
\hline & Triploid & $1.02 \pm 0.08$ & $1.00 \pm 0.2$ & $1.01 \pm 0.1$ & $0.88 \pm 0.2$ & $1.18 \pm 0.1$ \\
\hline \multirow[t]{2}{*}{$C 20: 5 n-3$} & Diploid & $2.95 \pm 0.2$ & $2.58 \pm 0.3$ & $2.93 \pm 0.3$ & $2.45 \pm 0.5$ & $2.94 \pm 0.6$ \\
\hline & Triploid & $2.90 \pm 0.2$ & $2.64 \pm 0.4$ & $2.67 \pm 0.6$ & $3.35 \pm 0.4$ & $2.65 \pm 0.4$ \\
\hline \multirow[t]{2}{*}{$C 22: 5 n-3$} & Diploid & $1.08 \pm 0.09$ & $1.01 \pm 0.1$ & $1.06 \pm 0.2$ & $1.31 \pm 0.5$ & $1.02 \pm 0.1$ \\
\hline & Triploid* & $0.96 \pm 0.1^{\mathrm{a}}(\mathrm{P})$ & $0.96 \pm 0.2^{\mathrm{a}}(\mathrm{P})$ & $1.66 \pm 0.5^{\mathrm{b}}$ & $1.24 \pm 0.3^{\mathrm{ab}}$ & $1.01 \pm 0.2^{\mathrm{ab}}$ \\
\hline \multirow[t]{2}{*}{ C22:6n-3 } & Diploid & $15.8 \pm 2.2$ & $13.7 \pm 1.3$ & $15.0 \pm 3.4$ & $11.0 \pm 3.1$ & $14.2 \pm 2.5$ \\
\hline & Triploid* ${ }^{*}$ & $13.5 \pm 1.7^{\mathrm{a}}(\mathrm{P})$ & $10.5 \pm 2.8^{\mathrm{a}}(\mathrm{P})$ & $12.2 \pm 2.4^{\mathrm{a}}$ & $17.0 \pm 3.9^{\mathrm{b}}$ & $12.9 \pm 3.3^{\mathrm{ab}}$ \\
\hline \multirow{2}{*}{$\begin{array}{l}\text { Total omega- } 3 \\
\text { fatty acids }\end{array}$} & Diploid & $20.8 \pm 2.4$ & $18.3 \pm 1.6$ & $20.2 \pm 3.8$ & $15.8 \pm 3.7$ & $19.0 \pm 3.5$ \\
\hline & Triploid* & $18.4 \pm 1.9^{\mathrm{a}}(\mathrm{P})$ & $15.2 \pm 2.5^{\mathrm{a}}(\mathrm{P})$ & $17.6 \pm 3.1^{\mathrm{ab}}$ & $22.4 \pm 4.5^{\mathrm{b}}$ & $17.7 \pm 3.9^{\mathrm{ab}}$ \\
\hline \multirow[t]{2}{*}{ C18:2n-6 } & Diploid & $9.68 \pm 0.8$ & $10.2 \pm 0.7$ & $10.0 \pm 0.4$ & $9.95 \pm 0.5$ & $10.4 \pm 0.3$ \\
\hline & Triploid & $10.2 \pm 0.8$ & $9.86 \pm 0.4$ & $9.35 \pm 0.8$ & $9.41 \pm 0.6$ & $9.67 \pm 0.6$ \\
\hline \multirow[t]{2}{*}{ C20:4n-6 } & Diploid & $2.48 \pm 0.1$ & $2.01 \pm 0.1$ & $2.21 \pm 0.3$ & $1.95 \pm 0.3$ & $2.36 \pm 0.4$ \\
\hline & Triploid & $2.20 \pm 0.2$ & $2.02 \pm 0.5$ & $1.95 \pm 0.3$ & $2.51 \pm 0.5$ & $1.91 \pm 0.5$ \\
\hline \multirow{2}{*}{$\begin{array}{l}\text { Total omega- } 6 \\
\text { fatty acids }\end{array}$} & Diploid & $12.2 \pm 0.8$ & $12.2 \pm 0.8$ & $12.2 \pm 0.1$ & $12.0 \pm 0.4$ & $13.1 \pm 0.8$ \\
\hline & Triploid & $12.4 \pm 0.7$ & $11.9 \pm 0.7$ & $11.3 \pm 1.2$ & $11.9 \pm 0.8$ & $11.6 \pm 0.7$ \\
\hline \multirow[t]{2}{*}{ Total PUFAs } & Diploid & $33.0 \pm 2.2$ & $30.5 \pm 2.1$ & $32.4 \pm 3.8$ & $28.4 \pm 4.3$ & $32.2 \pm 4.2$ \\
\hline & Triploid & $30.7 \pm 1.8$ & $27.0 \pm 2.3$ & $28.9 \pm 4.0$ & $34.4 \pm 4.9$ & $29.3 \pm 4.4$ \\
\hline \multirow[t]{2}{*}{ Total UFAs } & Diploid* & $61.0 \pm 0.9(\mathrm{D})$ & $59.6 \pm 0.4^{\mathrm{b}}$ & $60.0 \pm 0.2^{\mathrm{ab}}$ & $58.5 \pm 1.3^{\mathrm{a}}$ & $59.6 \pm 0.7^{\mathrm{ab}}$ \\
\hline & Triploid & $60.4 \pm 0.4^{\mathrm{ab}}(\mathrm{P})$ & $59.6 \pm 0.6^{\mathrm{ab}}(\mathrm{P})$ & $58.1 \pm 2.3^{\mathrm{a}}$ & $61.3 \pm 0.9^{b}$ & $58.5 \pm 2.1^{\mathrm{a}}$ \\
\hline \multirow{2}{*}{$\begin{array}{r}\text { Omega-3/ } \\
\text { omega-6 }\end{array}$} & Diploid & $0.59 \pm 0.09$ & $0.66 \pm 0.05$ & $0.62 \pm 0.1$ & $0.81 \pm 0.2$ & $0.69 \pm 0.07$ \\
\hline & Triploid & $0.68 \pm 0.09$ & $0.80 \pm 0.1$ & $0.65 \pm 0.08$ & $0.54 \pm 0.09$ & $0.67 \pm 0.1 \mathrm{z}$ \\
\hline
\end{tabular}

skin gelatin of diploid and triploid C. gariepinus (Karami et al. 2016b). In contrast, the muscle of diploid and triploid tench Tinca tinca showed differences in free AA composition, indicating species-specific differences (Buchtová et al. 2005). In the present study, the most dominant AAs in both ploidies control groups were glutamic acid and aspartic acid, representing about 2.7 and $1.8 \mathrm{mg} \mathrm{g}^{-1}$ (wet weight), respectively. These AAs are proven to have a fundamental role in the wound healing process in traumatized rats 


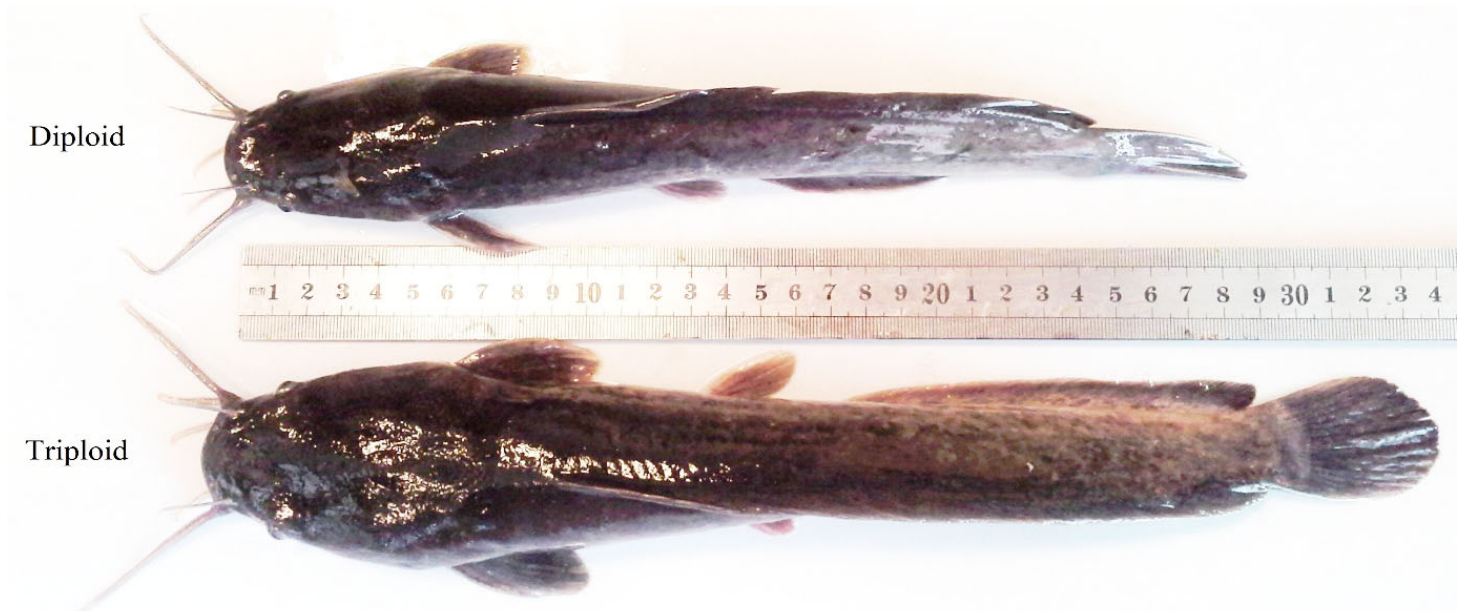

Fig. 2. Differences in length between full-sibling $14 \mathrm{wk}$ old diploid and triploid Clarias gariepinus used in this study

(Chyun \& Griminger 1984). Anticancer activity of glutamic acid (Dutta et al. 2013) and the impacts of aspartic acid in enhancing athletic performance (Meehan 2016) may suggest C. gariepinus as a rich source of nutrients for human health.

Unexposed diploid fish might show superior nutritional values compared to triploids due to a higher level of C22:6n-3 and total omega-3 FAs in their skeletal muscle. Contrary to our results, triploid Salmo salar had a significantly higher percentage of C22:6n-3 compared to diploids (Taylor et al. 2013), while diploid and triploid salmon $(\mathrm{O}$. masou) had a comparable FA composition in the muscle (Wang et al. 2015). These results highlight the effect of ploidy and species-specific differences in FA metabolism.

The increase in the number of genes in triploid organisms compared to diploids may change nutritional composition such as fat content, $\mathrm{AA}$, and FA composition (Buchtová et al. 2005, Taylor et al. 2013). No significant differences in AAs, most of the FAs, and proximate composition indicated that gene dosage had minimal impacts on nutritional values in $C$. gariepinus. In polyploid organisms, duplicated genes may interact through recombination, gene conversion, epigenetic silencing, or other mechanisms (Wendel 2000). The observed lack of differences in the levels of AAs and most FAs or protein, lipid, moisture, and ash contents in C. gariepinus may be attributed to the silencing of one of the 3 alleles which modify gene expression in triploid fish. Woods \& Buth (1984) showed a high level of gene copy silencing in tetraploid goldfish Carassius auratus.

Chemical pesticides used in agriculture impact the activity of biologically active molecules such as proteins, lipids, and carbohydrates (Singh \& Sharma 1998). Protein plays a key role in metabolic pathways (Suryavanshi et al. 2009) and in improving the health, growth, development, and disease resistance of organisms (Xu et al. 2016). Exposure to $28 \mu \mathrm{g} \mathrm{l}^{-1}$ chlorpyrifos significantly reduced protein content in the skeletal muscle of diploid Clarias gariepinus compared to the control group. Consistent with the present study, a decrease in protein content was observed in different tissues of $C$. batrachus following exposure to sublethal chlorpyrifos concentrations for $28 \mathrm{~d}$ (Narra et al. 2011). Possible explanations for the reduced protein content are the destruction or necrosis of cells, resulting in protein synthesis impairment (Bradbury et al. 1987), and the enhanced proteolytic activity in the muscle under pesticide exposure. In contrast, lipid composition showed no alteration throughout the study across each ploidy, which is consistent with our recent study where phenanthrene had no impacts on the serum lipid profile in C. gariepinus (Karami et al. 2016d). Changes in the muscle moisture content in diploid fish following chlorpyrifos treatments are in agreement with the alterations in moisture content in monocrotophos-exposed juvenile Indian carp Labeo rohita (Ramani et al. 2002). Alterations in moisture and ash contents have been suggested to be due to the reduction of food consumption and food conversion efficiency under stress (Nair \& Sherief 1998).

The decrease in levels of aspartic acid, serine, glutamic acid, histidine, alanine, tyrosine, valine, lysine, isoleucine, leucine, phenylalanine, and total AAs in diploid C. gariepinus exposed to $28 \mu \mathrm{g} \mathrm{l}^{-1}$ chlorpyrifos may be attributed to the utilization of AAs for energy provision to cope with the stress (Shobha Rani \& Janaiah 1991). Similarly, a reduction in free AA levels was observed in the muscle of $C$. batrachus after $28 \mathrm{~d}$ of exposure to 825 and $1650 \mathrm{\mu g} \mathrm{l}^{-1}$ chlorpyrifos (Narra et al. 2011). Fewer changes in AA levels in chlorpyrifos-exposed triploids may indicate the 
impact of ploidy on the adaptive mechanisms of fish following exposure to environmental stressors. In diploids, lower protein content and AAs at the high concentration of chlorpyrifos may highlight an interruption in AA synthesis followed by impairment in protein synthesis (Narra et al. 2011). Furthermore, these results may demonstrate the poor nutritional value of the farmed or wild diploid fish from areas with high chlorpyrifos concentrations. However, the extra set of chromosomes in triploid cells may neutralize the adverse impacts of the chlorpyrifos on AA synthesis and protein content of the muscle.

PUFAs, especially omega-3, are important for aquaculture, as they influence the nutritional value of the fillet (Manor et al. 2012). According to the findings of this study, either the 8.9 or the $17.5 \mu \mathrm{g} \mathrm{l^{-1 }}$ chlorpyrifos exposure caused an increase in levels of C18:0, C22:5n-3, C22:6n-3, and total omega-3 fatty acids and decreased the levels of C16:0 and total SFAs in triploid C. gariepinus. However, the chlorpyrifos exposures did not affect the level of omega-3 FAs in the muscle of diploid fish. Stearic acid (C18:0) is an SFA but is less efficiently absorbed by the body and, therefore, has limited bioavailability (Clarke et al. 1977, Kritchevsky 1994). In contrast, the association between the high C16:0 intake and various diseases has been suggested earlier (see review by Fattore \& Fanelli 2013). Long-chain highly unsaturated FAs including C20:5n-3, C22:6n-3, and C20:4n-6 are needed for normal growth and development in fish (Sargent et al. 1999). They are also a part of membrane phospholipids and are the precursors of biologically active eicosanoids (Sargent et al. 2002). In addition, C20:5n-3 and C22:6n-3 play a vital role in humans, including promoting cardiovascular health (Calder \& Yaqoob 2009). In contrast to triploids, diploid fish showed an increase in C16:0 and total SFA levels and a decrease in total UFA levels. In freshwater rosy barb Puntius conchonius, the sublethal concentration of phosphamidon, an OP insecticide, increased the level of free FAs in the liver and skeletal muscles (Gill et al. 1990). A few studies have shown the effects of pesticides on FA metabolism in fish species under controlled conditions due to alterations in the enzymes responsible for metabolism such as catalase, allantoinase, uricase, FA synthase (multienzyme complex characterized in fish species), and acetylCoA carboxylase (see review by OlivaresRubio \& Vega-López 2016).

No alterations in protein content, along with little change in the AA levels or composition in triploid fish, could indicate the better adaptability of triploid fish to environmental stressors. Earlier studies have found
protein-DNA interactions within organisms (Luscombe \& Thornton 2002, Stormo 2013). Also, OP pesticides are known to induce DNA damage to fish species (Ali et al. 2008). Therefore, extra DNA contents in triploid fish (Wendel \& Doyle 1998) might have resulted in alteration of gene expression and, consequently, fewer responses of triploids to chlorpyrifos exposure compared to their diploid counterparts.

We showed in this study that diploid and triploid $C$. gariepinus respond differently to the stress induced by chlorpyrifos exposure. Similarly, the increased level of C22:6n-3 and C20:5n-3 in freshwater clams Dipolodon chilensis was suggested as an adaptive mechanism to enhance their resistance to sewage discharges (Rocchetta et al. 2014). Further studies on other biomarkers are required to elucidate better the impacts of environmental stressors on polyploid fish.

This study showed that ploidy status had a small but significant influence on nutritional values in unexposed C. gariepinus. Chlorpyrifos at the concentrations applied in this study (up to $28 \mu \mathrm{g} \mathrm{l}^{-1}$ ) was observed to induce potentially harmful effects to diploid C. gariepinus. Significant changes in the muscle protein content and AA and FA compositions in diploid fishes in response to chlorpyrifos exposure suggest their application as sensitive indicators of aquatic environmental pollution. Dissimilar patterns of change in the levels of particular AAs and FAs, and in proximate composition between diploid and triploid fish following chlorpyrifos exposure highlight different mechanisms used by the fish from different genetic types to cope with the stress. In addition, no change in muscle protein content, little change in AA levels, and increased UFA levels in chlorpyrifos-exposed triploid C. gariepinus may highlight their higher resistance to environmental stressors as compared to the diploid fish. Moreover, higher growth of triploid C. gariepinus compared to diploids and their sterility (Karami \& Courtenay 2015), which limits their breeding with wild populations, could support application of triploid C. gariepinus as an alternative to their diploid counterparts for the aquaculture industry.

Acknowledgements. The authors thank the Ministry of Science and Technology and Innovation (MOSTI), Government of Malaysia, for funding this study (E-Science grant, 0102-05-SF0017).

\section{LITERATURE CITED}

Adewolu MA, Adeniji CA, Adejobi AB (2008) Feed utilization, growth and survival of Clarias gariepinus (Burchell 1822) fingerlings cultured under different photoperiods. Aquaculture 283:64-67 
Ali D, Nagpure NS, Kumar S, Kumar R, Kushwaha B (2008) Genotoxicity assessment of acute exposure of chlorpyrifos to freshwater fish Channa punctatus (Bloch) using micronucleus assay and alkaline single-cell gel electrophoresis. Chemosphere 71:1823-1831

Almeida JR, Oliveira C, Gravato C, Guilhermino L (2010) Linking behavioural alterations with biomarkers responses in the European seabass Dicentrarchus labrax L. exposed to the organophosphate pesticide fenitrothion. Ecotoxicology 19:1369-1381

AOAC (Association of Official Analytical Chemists) (1984) Official methods of analysis, 14th edn. Association of Official Analytical Chemists, Washington, DC

AOAC (1999) Official methods of analysis, 16th edn. Association of Official Analytical Chemists, Washington, DC

AOAC (2000) Official methods of analysis, 17th edn. Association of Official Analytical Chemists, Gaithersburg, MD

Barron MG, Plakas SM, Wilga PC (1991) Chlorpyrifos pharmacokinetics and metabolism following intravascular and dietary administration in channel catfish. Toxicol Appl Pharmacol 108:474-482

Bradbury SP, Symonik DM, Coats JR, Atchison GJ (1987) Toxicity of fenvalerate and its constituent isomers to the fathead minnow, Pimephales promelas, and bluegill, Lepomis macrochirus. Bull Environ Contam Toxicol 38: 727-735

*Buchtová H, Smutná M, Vorlová L, Svobodová Z, Flajšhans M (2005) Amino acid composition of muscle proteins of diploid and triploid tench (Tinca tinca, Linnaeus 1758). Acta Vet Brno 74:329-337

* Calder PC, Yaqoob P (2009) Omega-3 polyunsaturated fatty acids and human health outcomes. Biofactors 35:266-272

* Chyun JH, Griminger P (1984) Improvement of nitrogen retention by arginine and glycine supplementation and its relation to collagen synthesis in traumatized mature and aged rats. J Nutr 114:1697-1704

Clarke SD, Romsos DR, Leveille GA (1977) Differential effects of dietary methyl esters of long-chain saturated and polyunsaturated fatty acids on rat liver and adipose tissue lipogenesis. J Nutr 107:1170-1181

* Dunbar BS, Bosire RV, Deckelbaum RJ (2014) Omega 3 and omega 6 fatty acids in human and animal health: an African perspective. Mol Cell Endocrinol 398:69-77

* Dutta S, Ray S, Nagarajan K (2013) Glutamic acid as anticancer agent: an overview. Saudi Pharm J 21:337-343

Ebrahimi M, Rajion MA, Goh YM, Sazili AQ (2012) Impact of different inclusion levels of oil palm (Elaeis guineensis Jacq.) fronds on fatty acid profiles of goat muscles. J Anim Physiol Anim Nutr (Berl) 96:962-969

Fast AW, Pewnim T, Keawtabtim R, Saijit R, Te FT, Vejaratpimol R (1995) Comparative growth of diploid and triploid Asian catfish Clarias macrocephalus in Thailand. J World Aquacult Soc 26:390-395

Fattore E, Fanelli R (2013) Palm oil and palmitic acid: a review on cardiovascular effects and carcinogenicity. Int J Food Sci Nutr 64:648-659

Gill HK, Garg H (2014) Pesticides: environmental impacts and management strategies. In: Larramenday ML, Solenski S (eds) Pesticides: toxic aspects. InTech. Rijeka, p 187-230

Gill TS, Pande J, Tewari H (1990) Sublethal effects of an organophosphorus insecticide on certain metabolite levels in a freshwater fish, Puntius conchonius Hamilton. Pestic Biochem Physiol 36:290-299

Gold JR, Avise JC (1976) Spontaneous triploidy in the California roach Hesperoleucus symmetricus (Pisces: Cyprinidae). Cytogenet Cell Genet 17:144-149
Jin Y, Liu Z, Peng T, Fu Z (2015) The toxicity of chlorpyrifos on the early life stage of zebrafish: a survey on the endpoints at development, locomotor behavior, oxidative stress and immunotoxicity. Fish Shellfish Immunol 43:405-414

Karami A, Courtenay SC (2015) Glutathione S-transferase activities in African catfish injected with $\beta$-naphthoflavone: effects of ploidy, gender, dose, and sampling time. Environ Monit Assess 187:681

K Karami A, Christianus A, Ishak Z, Courtenay SC, Syed MA, Azlina MN, Noorshinah H (2010) Effect of triploidization on juvenile African catfish (Clarias gariepinus). Aquacult Int 18:851-858

K Karami A, Araghi PE, Syed MA, Wilson SP (2015a) Chromosome preparation in fish: effects of fish species and larval age. Int Aquat Res 7:201-210

Karami A, Teh SJ, Zakaria MP, Courtenay SC (2015b) Ploidy-, gender-, and dose-dependent alteration of selected biomarkers in Clarias gariepinus treated with benzo[a]pyrene. J Environ Sci (China) 38:95-102

* Karami A, Goh YM, Jahromi MF, Lazorchak JM, Abdullah M, Courtenay SC (2016a) Diploid and triploid African catfish (Clarias gariepinus) differ in biomarker responses to the pesticide chlorpyrifos. Sci Total Environ 557-558: 204-211

Karami A, Karbalaei S, Zad Bagher F, Ismail A, Simpson SL, Courtenay SC (2016b) Alterations in juvenile diploid and triploid African catfish skin gelatin yield and amino acid composition: effects of chlorpyrifos and butachlor exposures. Environ Pollut 215:170-177

Karami A, Omar D, Lazorchak JM, Yap CK, Hashim Z, Courtenay SC (2016c) A comparison of biomarker responses in juvenile diploid and triploid African catfish, Clarias gariepinus, exposed to the pesticide butachlor. Environ Res 151:313-320

Karami A, Romano N, Hamzah H, Simpson SL, Yap CK (2016d) Acute phenanthrene toxicity to juvenile diploid and triploid African catfish (Clarias gariepinus): Molecular, biochemical, and histopathological alterations. Environ Pollut 212:155-165

Kritchevsky D (1994) Stearic acid metabolism and atherogenesis: history. Am J Clin Nutr 60:997S-1001S

Luscombe NM, Thornton JM (2002) Protein-DNA interactions: amino acid conservation and the effects of mutations on binding specificity. J Mol Biol 320:991-1009

* Mamun MIR, Park JH, Choi JH, Kim HK and others (2009) Development and validation of a multiresidue method for determination of 82 pesticides in water using GC. J Sep Sci 32:559-574

* Manor ML, Weber GM, Salem M, Yao J, Aussanasuwannakul A, Kenney PB (2012) Effect of sexual maturation and triploidy on chemical composition and fatty acid content of energy stores in female rainbow trout, Oncorhynchus mykiss. Aquaculture 364-365:312-321

* Marimuthu K, Muthu N, Xavier R, Arockiaraj J, Rahman MA, Subramaniam S (2013) Toxicity of buprofezin on the survival of embryo and larvae of African catfish, Clarias gariepinus (Bloch). PLOS ONE 8:e75545

Mayer I (2015) Are triploid salmonids the future for aquaculture and fishery management? 145th Annual Meeting of the American Fisheries Society, Portland, OR

Mazanti L, Rice C, Bialek K, Sparling D and others (2003) Aqueous-phase disappearance of atrazine, metolachlor, and chlorpyrifos in laboratory aquaria and outdoor macrocosms. Arch Environ Contam Toxicol 44:67-76

Meehan K (2016) Composition for enhancing athletic performance. Google Patents. https://www.google.com/ patents/US9271983 
Moore MT, Schulz R, Cooper CM, Smith S Jr, Rodgers JH Jr (2002) Mitigation of chlorpyrifos runoff using constructed wetlands. Chemosphere 46:827-835

Murayama Y, Hijikata M, Kojima K, Nakakuki M, Noda M, Kajishima T (1986) The appearance of diploid-triploid and diploid-triploid-tetraploid mosaic individuals in polyploid fish, ginbuna (Carassius auratus langsdorfii). Experientia 42:187-188

Nair JR, Sherief PM (1998) Acute toxicity of phenol and long-term effects on food consumption and growth of juvenile rohu Labeo rohita (Ham.) under tropical conditions. Asian Fish Sci 10:179-187

* Narra MR, Begum G, Rajender K, Rao JV (2011) Sub-lethal effect of chlorpyrifos on protein metabolism of the food fish Clarias batrachus and monitoring of recovery. Toxicol Environ Chem 93:1650-1658

Nwani CD, Ugwu DO, Okeke OC, Onyishi GC, Ekeh FN, Atama C, Eneje LO (2013) Toxicity of the chlorpyrifosbased pesticide Termifos ${ }^{\circledR}$ : effects on behaviour and biochemical and haematological parameters of African catfish Clarias gariepinus. Afr J Aquat Sci 38:255-262

OECD (Organisation for Economic Cooperation and Development) (1994) Fish, prolonged toxicity test: 14 day study. OECD Guidelines for the Testing of Chemicals, Paris

OECD (2011) Test no. 234: fish sexual development test. OECD Guidelines for the Testing of Chemicals, Section 2. Paris

Oliva-Teles A, Kaushik SJ (1990) Growth and nutrient utilization by $0+$ and $1+$ triploid rainbow trout, Oncorhynchus mykiss. J Fish Biol 37:125-133

* Olivares-Rubio HF, Vega-López A (2016) Fatty acid metabolism in fish species as a biomarker for environmental monitoring. Environ Pollut 218:297-312

* Piferrer F, Beaumont A, Falguière JC, Flajšhans M, Haffray P, Colombo L (2009) Polyploid fish and shellfish: production, biology and applications to aquaculture for performance improvement and genetic containment. Aquaculture 293:125-156

Rajion MA, McLean JG, Cahill RN (1985) Essential fatty acids in the fetal and newborn lamb. Aust J Biol Sci 38:33-40

Ramani MB, Mercy TA, Nair JR, Sherief PM (2002) Changes in the proximate composition of Labeo rohita (Ham.) exposed to sublethal concentrations of monocrotophos. Indian J Fish 49:427-432

Rocchetta I, Pasquevich MY, Heras H, de Molina M del CR, Luquet CM (2014) Effects of sewage discharges on lipid and fatty acid composition of the Patagonian bivalve Diplodon chilensis. Mar Pollut Bull 79:211-219

Sargent J, Bell G, McEvoy L, Tocher D, Estevez A (1999) Recent developments in the essential fatty acid nutrition of fish. Aquaculture 177:191-199

Sargent JR, Tocher DR, Bell JG (2002) The lipids. In: Halver JE, Hardy RW (eds) Fish nutrition, 3rd edn. Academic Press, San Diego, CA, p 181-257

Shobha Rani VJ, Janaiah C (1991) Ammonia metabolism in freshwater teleost, Clarias batrachus (Linn.) on exposure to trichlorfon. Bull Environ Contam Toxicol 46: 731-737

Signa G, Di Leonardo R, Vaccaro A, Tramati CD, Mazzola A, Vizzin S (2015) Lipid and fatty acid biomarkers as proxies for environmental contamination in caged mussels Mytilus galloprovincialis. Ecol Indic 57:384-394

Silva CO, Simões T, Novais SC, Pimparel I and others (2017) Fatty acid profile of the sea snail Gibbula umbilicalis as a

Editorial responsibility: Helmut Segner, Bern, Switzerland biomarker for coastal metal pollution. Sci Total Environ 586:542-550

Singh RK, Sharma B (1998) Carbofuran induced biochemical changes in Clarias batrachus. Pestic Sci 53:285-290

Stormo GD (2013) Introduction to protein-DNA interactions: structure, thermodynamics, and bioinformatics. Cold Spring Harbor Laboratory Press, New York, NY

Suryavanshi U, Sreepada RA, Ansari ZA, Nigam S, Badesab $\mathrm{S}$ (2009) A study on biochemical changes in the penaeid shrimp, Metapenaeus monoceros (Fabricius) following exposure to sublethal doses of organochlorine pesticide (endosulfan). Chemosphere 77:1540-1550

* Taylor JF, Sambraus F, Mota-Velasco J, Guy DR and others (2013) Ploidy and family effects on Atlantic salmon (Salmo salar) growth, deformity and harvest quality during a full commercial production cycle. Aquaculture 410-411:41-50

* Tidwell JH, Allan GL (2001) Fish as food: aquaculture's contribution. EMBO Rep 2:958-963

Tocher DR (2003) Metabolism and functions of lipids and fatty acids in teleost fish. Rev Fish Sci 11:107-184

Toko I, Fiogbe ED, Koukpode B, Kestemont P (2007) Rearing of African catfish (Clarias gariepinus) and vundu catfish (Heterobranchus longifilis) in traditional fish ponds (whedos): effect of stocking density on growth, production and body composition. Aquaculture 262:65-72

USEPA (United States Environmental Protection Agency) (2002). Interim reregistration eligibility decision for chlorpyrifos. http://www.epa.gov/pesticides/reregistration/ REDs/chlorpyrifos ired.pdf

WWang CA, Xu QY, Bai QL, Yin JS, Jia ZH (2015) Comparison of growth performances, nutritional composition in muscle of diploid and triploid masu salmon (Oncorhynchus masou B., 1856). Turk J Fish Aquat Sci 15:127-135

Wendel JF (2000) Genome evolution in polyploids. In: Doyle JJ, Gaut BS (eds) Plant molecular evolution. Springer, Dordrecht, p 225-249

Wendel JF, Doyle JJ (1998) Phylogenetic incongruence: window into genome history and molecular evolution. In: Soltis DE, Soltis PS, Doyle JJ (eds) Molecular systematics of plants II: DNA sequencing. Springer, New York, NY, p 265-296

Woods TD, Buth DG (1984) High level of gene silencing in the tetraploid goldfish. Biochem Syst Ecol 12:415-421

Wu G (2009) Amino acids: metabolism, functions, and nutrition. Amino Acids 37:1-17

* Wu G (2013) Functional amino acids in nutrition and health. Amino Acids 45:407-411

Xiao J, Zou T, Chen Y, Chen L and others (2011) Coexistence of diploid, triploid and tetraploid crucian carp (Carassius auratus) in natural waters. BMC Genet 12:20

Xu J, Wu P, Jiang WD, Liu Y and others (2016) Optimal dietary protein level improved growth, disease resistance, intestinal immune and physical barrier function of young grass carp (Ctenopharyngodon idella). Fish Shellfish Immunol 55:64-87

Yadav IC, Devi NL, Syed JH, Cheng Z, Li J, Zhang G, Jones KC (2015) Current status of persistent organic pesticides residues in air, water, and soil, and their possible effect on neighboring countries: a comprehensive review of India. Sci Total Environ 511:123-137

Zuraini A, Somchit MN, Solihah MH, Goh YM and others (2006) Fatty acid and amino acid composition of three local Malaysian Channa spp. fish. Food Chem 97:674-678

Submitted: December 19, 2016; Accepted: June 10, 2017

Proofs received from author(s): July 27, 2017 